\title{
The stability of the world image in creating a global sense of security
}

\author{
Stanisław Ciupka ${ }^{1}$ \\ ${ }^{1}$ Department of Law and Social Science, Bielsko-Biala School of Finance and Law \\ Tańskiego 5, 43-300 Bielsko-Biata - Poland
}

\begin{abstract}
The concept of safety has changed over the centuries and has been taken into account by many different factors. This was because some stability only covered some areas of human life and others were subject to change. Often the changes were created by different temporary fashions and trends. By referring to different philosophical concepts over the centuries, we would like to point out that many researchers claim that there is a constant trend to question a stable, certain world picture in global dimensions. If this thesis is true, then it begins to live and function, both in the individual and social dimension in an increasingly dangerous global world
\end{abstract}

Index Terms - Security, man, mankind, stability, multidimensional security.

\section{INTRODUCTION}

The concept of a global sense of security is an intersubjective issue, combining many areas of human knowledge, a broader aspect that transcends the feelings, beliefs and safety of the human person. Of course, the human person is involved in this process, his or her understanding and feeling of security, but at the same time it is building that security as a social process. In the following comments we would like to draw attention to the important role in creating a global sense of security, which is provided by a stable and confident world picture. Finding and defining our place in global cultural phenomena is one of the important conditions that allow us to face the challenges of the surrounding world in which we operate. In his research, A. W. Ziętek (Ziętek 2019, compare Rembierz 2019, pp. 1-17) claims that contemporary symbols related to cultural identity acquire new meaning, shaping patterns of cohesion, disintegration, conflict, and thus cultural security significantly influences the level of the whole world security. The second extremely important component that gives us the conviction of stability and certainty in global security stems from the conviction that there is a certain political, social and economic order in the world, because this conviction is a symbolic experience of the existence of a stable world. Meanwhile, many researchers claim that: In modern times, we are undoubtedly dealing with a crisis

ASEJ - Scientific Journal of Bielsko-Biala School of Finance and Law

Volume 24, No 2 (2020), 5 pages

DOI: $10.5604 / 01.3001 .0014 .3278$

Received: 10.06.2020; Accepted: 24.06.2020 of Western European civilization, with very different causes, course and consequences. Certainly of great importance is the permanent economic crisis, related to the malfunctioning, based on the statist principle of the command and control economy, of the economic system of most Western European countries and the USA, as some experts in economic issues point out. (Polak 2015, p. 151).

Today's man still functions among a multitude of signs, symbols, and this gives him an inner conviction about the certainty of his life, his actions, dynamizing to individual but also collective initiatives. The lack of conviction of an individual and society about the permanence of security, stability of the image of the world, is a significant problem of individual and social life. In our arguments we will try to point out the role of the worldview in creating the world's conviction about the existence of global security, and to verify the thesis, which has been proclaimed by many, that contemporary culture does not fulfill its role in this respect.

\section{STABILITY OF THE WORLD AND ITS IMAGE}

The social perception of the world in building global security is an appropriate fundamental philosophical consideration. Man is constantly searching, in one form or another, for the answer to the question: what is what? This is due to the desire to obtain a sense of order in human life in the world. One of the basic intellectual needs of man is the need for a holistic vision of reality. In this vision, questions about the meaning of life, the hierarchy of values, ethical norms, the origin of the universe and the laws of its development appear as central problems (Życiński 1989, p. 11). People want to find an order that incorporates human existence into the mechanisms of nature and history. Since the earliest days of human civilization, the notion of the safety of existence, stability and certainty of the world has changed its scope, dimensions and forms, but its essence has remained constant. Different conditions of this phenomenon were subject to change, but the sense and character were not subject to change. The concept of existential security is the fulfilment of the Roman word secura, which

Regular research paper: Published 06.2020

Corresponding author's e-mail: stanislaw.ciupka@op.pl

Copyright $(\mathbb{C} 2018$ This is an open access article distributed under the Creative Commons Attribution CC-BY-NC 4.0 License. 
means freedom from worries, and the term securitas can be identified with the stability of the world and its image (Malinowski 2018, p.7). The philosophical thought wanted to do this in various ways. From antiquity, let us mention the Ionic natural philosophers who looked for archetypes in water, boundlessness, fire, breathing, the concept of the Heraclitus of Ephesus, who explained everything about nature through changeability, and Parmenides of Elea spoke about permanence and unchangeability of being. Plato preached the principle that the world is wisely shaped, because its foundation is eternal and unchangeable ideas. European ancient times gave us a vision of the cosmos as a world of unchangeable ideas and corresponding beings. Such philosophical views, only generally mentioned here, allowed the man of that time to base his life on a worldview that contained the understanding of the world and showed the basic principles of social life and at the same time secured the original source of social order. A common perception of the world was the framework and boundaries of society, that is, people living together (Wójcik 2002, p. 24). The ancient society shaped in this way was a community whose stability and certainty of the world was secured by common interpretations of itself and the world, which were expressed in the symbolism of myths, religions that preceded rational and theoretical reflection. Today the word myth does not have a very good connotation. However, let us recall U.'s comments. Nicola, who tells us today: The Greek word $<$ mythos $>$ means speech, story, especially about the deeds of heroes and gods. Using myth, pre-philosophical thought symbolically explained, using examples from the cited stories, the great issues concerning the beginnings of the world, humanity and culture (...) it was noted that myth always has an inner coherence and is capable of expressing deep levels of understanding (in a prerational, symbolic, aesthetic way) and can therefore be considered as a kind of autonomous thought, different from scientific thought and not comparable to it. (Nicola 2006, 20). In our times, the sense of stability and certainty of the image of the world from mythological thinking has been replaced by the introduction of scientific and rational reflection. What a beautiful story about the world and its stability, which myths told, was full of symbols, values, justifications for social life, but was created outside the area of critical reflection. When philosophical thought comes to the fore, which begins to assign the most important role to rational cognition, a conflict arises between looking at the world through mythical thinking. Skepticism is born about the mythical vision, tendencies appear, undermining seemingly unchanging and eternal traditions and habits. The world is disenchanted, its image based on the certainty of faith disappears. Society is deprived of the foundation of truth that allowed building human culture. The crisis of Western European civilization signalled earlier and the loss of the sense of stability and certainty of the world's image, thus shaking global security, apart from economic conditions: (...) has a much deeper foundation: philosophical, moral and worldview, which should be found in the departure from the principles that formed its framework, the pillars of which were realistic, classical ancient and medieval philosophy, Roman law and Roman Catholic religion.
Meanwhile, the human activity of everyday life and belief in meaning, meaning, meaning, and general issues depend on the perception of the world, and on the emotional attitude towards it. Having the certainty of beliefs allows to remove doubts, enables to formulate final values which should be guided in life. If a person does not have a stable worldview, it is not easy for him or her to lead an authentic, unadulterated life based on true beliefs, additionally accepted through an accepted emotional relationship (Ortéga, Gasset 1993, p. 62). Scientific approaches alone do not often evoke a lively reaction: Science explains reality very well, but does not allow to understand it. The components of the worldview should be meaningful - apart from information, they have to carry understanding, emotional attitude, constitute the basis for creating one's own hierarchy of values and setting goals. Thus, the worldview is located closer to faith than thinking (Hennig 2015, p.75). The importance of a common perception of the world is significantly highlighted by another thinker who notes that: (...) permeates the whole society and guides its actions. A collective mentality that defines attitudes, dictates choices, strengthens superstitions and directs social movements is a civilisational fact. (...) These basic values, these psychological structures, are what decides about the inability of some civilizations to lead to others, what separates them and what differentiates them most (Braudel 2006, p. 56). Meanwhile, in every epoch in which there is a loss of faith in the images of the world, in the interpretations of the world, and thus in the current culture, the faith of man and society in themselves may be shaken, even, as some thinkers say, a return to the times of barbarism. The great totalitarianisms of the twentieth century (Hitlerism, Stalinism) convince us of this too clearly (Polit 2005, p. 89). Beliefs and religions have a huge impact on building a safe world of all societies, in shaping a stable, secure world image in human consciousness. However, since the Enlightenment, the role of religion in the issue we are discussing is increasingly being questioned. The conviction that there is no need for religion, God is becoming more and more preached. There is a growing conviction that we can speak of the world's independence. Without a clear-cut decision as to whether or not this world has been abandoned by God, there is a significant and influential group of people who are convinced that nature is governed by its laws, and that the only person who has the right to interfere in this world is man. And yet F. Nietzsche will write: Crazy Man - You have probably heard of this madman who lit a lantern in the bright morning, ran around the marketplace and kept screaming: "I am looking for God! I'm looking for God. As there were many who did not believe in God, there was no end to laughter. <Is God gone somewhere? >> Said one. <He got lost like a child? <Or maybe he is hiding? Is he afraid of us? Did he get on the ship? He wandered out? That's how they shouted and laughed through each other. $<$ What happened to God? He called out. - I'll tell you! We killed him - you and me. We're all his murderers! (Nietzsche 2009, pp. 137-138). The observed distance towards transcendence, religion, results in man on the one hand in excessive activism, because his power over reality increases, but on the other hand, he is deprived of any reasonable justification for his activity. Additionally, 
science likes to play the role of religion: This happens when the great successes of science in studying the world are mistaken for solving existential human problems and for solving all problems in general. The temptation of scientism, i.e. the extension of the scientific method to absolutely all areas of human affairs, is a very strong temptation. People often succumb to it, fascinated by the effectiveness of the scientific method in their areas of knowledge. (...) But this temptation breaks down hopelessly against two barriers. The first one, personal and hardly communicable to others, is the existential experience of man, such as: suffering, death, the search for the meaning of life, the choice between good and evil. The intensity of such experiences can be so great that any attempt to neutralize them by means of referring to various rules (...) turns out to be completely powerless. The second barrier against which scientist's temptations are broken down is the results of a responsible philosophy of science, which sets the boundaries of the scientific method (Heller 2017, pp. 8-9). In the absence of moral signposts or by deliberately rejecting them, we lean towards a simple rule of technical feasibility, i.e. we do everything that is feasible (Henning 2015, p. 76). By losing the ability to extract the unconscious, i.e. these mythical views of reality that ancient people had, we lose the most important sources of human thinking and action. We are breaking down the image of a stable, full, safe world. And yet, the perception of the world was and is and should be the inspiration for the concept of a safe world. Ontological orientation always sets the framework for human involvement in this world. Today, a stable image of the world has, as researchers say (Malinowski 2018, p. 8; Wolfers 1962, p. 150; Zięba 2008, p. 16; Pietras, Wojtaszczyk 2016, p. 20) a so-called subjective and objective character. The subjective character of a stable, safe image of the world means the lack of states of strong emotions, fear, a sense of threat, fear of losing it and that the essential values of human life, i.e. the conviction of personal safety, are at risk. In objective terms, the state of security of the world means the lack of clear threats to the existence of people and the institutions of social life built by them, the lack of threats to important values of civilization. Of course, it is natural for the world's models to change, i.e. new ones are formulated in place of the existing models. Our European image of the world has been and is subject to such variability in this respect. Let us return once again to the philosophy of the Enlightenment and the Cartesian method of doubt that emerged at that time, which philosophy also extended to the area of social life. Descartes in epistemology introduced into philosophy the concept of freedom in choosing the truth, calling such a process a speculative reasoning, introduced into human thinking freedom, instability of concepts, freeing us from the limitations of reality. There is actually no rule, because even concepts that are clear according to Descartes do not provide any constant criterion (Maritain 2005, p. 116; Wojtasik 2007, p. 139). The ultimate raison d'être of human perfection, the creator and model for the work of creation, is not God, but acting on the basis of the rational logic of Reason. It is reason that defines what reality is, gives the image of the world, there is a break in the close relationship between cognition and reality, there is a separation of mind and senses: The Descartesian world is divided into two (exclusionary!) types of substances: stretched substances, i.e., carnal substances and thinking substances, i.e., spiritual substances. For Descartes, souls were only human, and plants and animals were only soulless machines. This kind of dualism had an additional epistemological motivation (or consequence): in an unquestionable way, we can only know the states of our soul, that is, the experience of the thinking person, that is, of the self-aware subject; the knowledge of the external bodily substances for us does not have this quality, moreover, in fact, we cannot even be sure of their existence (Wojtasik 2015, p. 139). Although Descartes reserved that he intended to apply his views to the transformation of himself and not to seek to change morality, religion, social life, the state, the first followers of his philosophical path without the slightest scruples have already transferred his method of doubt into the area of social life. Thus, the stability and certainty of the image of the world was shaken, which must also have been connected with social security. Another philosophical trend in the reflection on the worldview of man is important in this period, we mean the concept of mind as a pure J. Locke'a. He proclaimed the conviction that it is necessary to reject all beliefs and knowledge acquired in the process of the original experience of the world. He strongly denied that before we start to critically explore reality, we are already connected to the world by life. The philosophers of the Enlightenment period wanted to remove all truths, traditions, goblins, superstitions, magic, and yet the stability of the world's image is also based on these realities (Henning 2015, p. 80). In the nineteenth century, the stable image of the world is intensively questioned by the then poets, revolutionists, anarchists, socialists. Romantics wanted to create a man who, according to them, was not subject to superstition and the truths of faith, and at the same time open to manifestations of emotionality and volitionality. They postulated the individualism of feeling reality, a positive value for them is to be guided by emotions, and according to them the first place should be given to act in accordance with their conscience, feeling, desire. This is how the human world is shaped in this period, in which the awareness of feelings in integrating societies is growing and at the same time it meets rationalistic and naturalistic tendencies (Kuderowicz 1989, p. 386.) A new image of the world is being drawn, in which social life appears as an important factor influencing the experiences of the individual, as well as a means of shaping the individuality and identity of the human person. The indefiniteness of the image of the world, its uncertainty transmitted by Romanticism is strongly revived in the protest movements of the second half of the 20th century, and these movements were extremely strong and set the tone for contemporary culture. The leaders of these movements praised and liked to be on the margins of public life, as this enabled them to reject the current lifestyle and certain behaviour in social life. They consciously put themselves outside the framework of social, political and moral life, because in this way they were able to protest and undermine the moral order in force. The stability and certainty of the image of the 20th century world was questioned by the New Age movements which led and continue to lead a revolt of 
spirituality which, in their opinion, is not only disenchanted but also devoid of all elements of sacrum. The beliefs that the New Age brings to today's image of the world are elements of pantheism, reincarnation, proclaiming the conviction that the nature of our reality as well as man is spiritual, and man is a sleeping God who should be awakened by changing his consciousness (Henning 2015, p. 83). A hit on the stability of the image of the world, both in the individual and in society as a whole, was the emergence of postmodernism, a direction that proclaims that the existence of objective truth is a thought and a preaching of the loss of nostalgia for absolute truth by the human world, and a hit on the concepts of world-view certainty of society. The supporters of postmodernism proclaimed the ignorance of the world, even denying man the certainty that anything exists. The reality in which we are supposed to live is fluid, uncertain, full of mystery. The mentioned romantic current with its significant emphasis has a feeling, postmodern destruction of the concept of truth, the New Age movement calling for a new spirituality fits into the concept of undermining the foundations of human society, destroying the stability and certainty of the image of the world. They sow and sow the idea of doubt, attack inherited truths about their own community, so the identity and worldview of the community is shaken, and yet on them a social sense of security is built. The contemporary, influential thinker R. Scruton calls the promotion of such ideas oikophobia, a kind of aversion to the global human home (Scruton 2004, p. 36; same 2012, p. 385391).

\section{CONCLUSION}

Recalling, of course, in a nutshell, the views of the ancient world that built a stable, safe, certain image of the world in human society, and then the philosophical concepts of the XVII, XIX, XX century that modified this image of the world towards rebellion against a stable social reality, we wanted to point out that this constellation of stable principles of social coexistence creates an image of humanity in which people are only individuals remaining alone and do not act for the benefit of joint ventures (Bloom, 1997, p. 98 et seq.). Science has played a major role in shaking the stable, safe image of the world in contemporary man. The detailed sciences provide common features of the view of reality, which include unlimited cognition of the whole Cosmos, both in time and space. Reaching deep into the Universe, we get to know its uniqueness, but many researchers pay attention to the other side of this knowledge of the Universe, we have lost the knowledge of our place in time and space, and thus it is difficult to talk about the stability of human worldview. In addition, a worldview based on a break from being rooted in the experiences of past eras can certainly not give today's man a sense of stability. The constant development of science, according to some researchers, leads to constant questioning of scientific conclusions, findings, and thus makes people aware of a certain limitation of science. There is a tendency in today's world to question the foundations of one's own existence (Wildiers 1985, p. 66; Weber 2004, p. 137). The relativity of the notion of truth, its instability in the concepts of contemporary scientists is well illustrated by the following arguments: [..., outside the narrow field of logic and perhaps mathematics, there is no evidence. To put it simply, nothing can be proven. Although it is possible to give arguments and to examine critical views, outside of mathematics, our argumentation is never conclusive. (Popper 1997, p. 241). The aim of contemporary efforts of scientific cognition is not - in the opinion of some, not all, of course, scientists - to create a stable, secure, harmonious picture of the world in which the global human community could feel safe, but utilitarian research and use of particular elements of the reality that surrounds us (Becker 1995, p.26, Heening 2015, p.89). Such a picture of the world (of course - we emphasise once again - in some researchers of science) results in a lack of justifications for fundamental existential questions, a lack of lasting foundations on which we could build a stable individual and collective life. As the Polish researcher writes, the romanticisation of the world failed (Henning 2015, p. 92), i.e. an attempt to give a sense of commonness, mystery and dignity to the extraordinary. Destruction of authorities, rejection of tradition, the need for stable values, ethics of care, responsibility for the world, have deprived our contemporaneity of a stable and certain, in individual and global dimensions, image of the world, that is, the feeling that we live in a safe world was shaken. The image of the world, in the presented arguments, does not inspire optimism in terms of human safety, or is there, as some say, more of an animal than an angel in us. In the next article, which we would like to develop when the conditions are right, we would like to point out that we can try to build a more optimistic thesis about the stability and safety of the current world image.

\section{REFERENCES}

Becker C.,(2009) Państwo Boże osiemnastowiecznych filozofów, Wyd. Zysk i S-ka, Poznań.

Bloom A., (1997), Umysł zamknięty, Wyd. Zysk i S-ka, Poznań,

Braudel F., (2006), Gramatyka cywilizacji, Oficyna Naukowa, Warszawa .

Heller M., (2017), Nowa fizyka i nowa teologia, Copernicus Center, Kraków.

Henning K., (2015), Rola stabilności i pewności obrazu świata w budowaniu zbiorowego poczucia bezpieczeństwa, [w:] M. Fałdowska, A. Wielomski, Bezpieczeństwo we współczesnej myśli politycznej, Wyd. von borowiecky, Radzimin, s. 73-95.

Kuderowicz Z., Filozofia nowożytnej Europy. Państwowe Wyd. naukowe, Warszawa.

Maritain J., (2015), Trzej reformatorzy, Fronda- Apostolicum, WarszawaZąbki,.

Malinowski M. J., Bezpieczeństwo we współczesnym świecie. Istota zjawiska i jego uwarunkowania (refleksje osobiste ), [w:] Civitas Hominibus nr 13/2018, Wyd. Akademii Humanistyczno-Ekonomicznej Łódź, s. 7-13

Nicola U., (2006), Filozofia, Świat Książki, Warszawa .

Nietzsche F., (2009), Radosna wiedza, Wyd. Słowo/Obraz Terytoria, Gdańsk. Ortéga y Gasset J.,(1993), Wokół Galileusza, Wyd. Spacja, Warszawa 
Pietras M., Wojtaszczyk K. A. (red.), (2016), Polska w systemie bezpieczeństwa międzynarodowego. Oficyna Wydawnicza Aspra-Jr, Warszawa .

Polak R., (2015), Kryzys kultury filozoficznej europejskiego zachodu i jego konsekwencje w ujęciu Mieczysława Alberta Krąpca OP., [w:] M. Fałdowska, A. Wielomski, Bezpieczeństwo we współczesnej myśli politycznej, Wyd. von borowiecky, Radzimin, s. 151-167.

Popper K., (1997), W poszukiwaniu lepszego świata. Wykłady i rozprawy z trzydziestu lat. Książka i Wiedza, Warszawa.

Polit K., (2005), Kryzys cywilizacji Zachodu w myśli Jose Ortegi y Gasseta. Wyd. Uniwersytetu Marii-Curie Składowskiej,Lublin .

Rembierz M. Między wielokulturowością <wieży Babel> a zróżnicowaniami kulturowo pograniczami. Pedagogiczne poszukiwania i idee Tadeusza Lewowickiego w zakresie edukacji kształtującej relacje międzykulturowe, [w:] Edukacja Międzykulturowa 2019, nr 2(11), Wyd. Adam Marszałek: Wydział Etnologii i Nauk o Edukacji Cieszyn, s. 1-17.

Scruton, R., (2004), England and the Need for Nations, London, s. 36, cyt. za: Henning K., Rola stabilności i pewności obrazu świata w budowaniu zbiorowego poczucia bezpieczeństwa, dz. cyt., s. 84

Scruton R., (2012), Zielona filozofia. Jak poważnie myśleć o naszej planecie, Wydawnictwo ZYSK I S-KA, Poznań .

Weber M., (2004), Racjonalność. Władza. Odczarowanie. Wyd. Poznańskie, Poznań .

Wildiers N., (1985), Obraz świata a teologia, Wyd. PAX, Warszawa .

Wójcik A., (2002),Wolność i władza. Wydawnictwo ZNAK, Kraków .

Wojtasik J., (2007), Filozofia i życie. Wydawnictwo ZNAK, Kraków .

Wolfers A., Discord and collaboration. Essays on International politics. The Johns Hopkins Uniwerity, Baltimore, s. 150, cyt. za: Malinowski M. J., Bezpieczeństwo we współczesnym świecie. Istota zjawiska i jego uwarunkowania (refleksje osobiste), dz. cyt., s. 8

Zięba R., (2018), Wprowadzenie. Pozimnowojenny paradygmat bezpieczeństwa międzynarodowego, [w:] tegoż (red.), Bezpieczeństwo międzynarodowe po zimnej wojnie. Wyd. Akademickie i Profesjonalne, Warszawa, s. 16- 24.

Ziętek A. W., (2019), Bezpieczeństwo kulturowe w Europie, Wyd. Uniwersytetu M. Curie-Skłodowskiej, Lublin.

Życiński J., (1989), W kręgu nauki i wiary, Cieszyńska Drukarnia Wydawnicza, Kalwaria. 